\title{
Local Adaptive Thresholding Menggunakan Metode Sauvola sebagai Tahapan Pra Pengolahan pada Data Citra Isyarat EKG (Elektrokardiogram)
}

\author{
Mohammad Rofi'i $i^{(a) *}$, dan Diah Rahayu Ningtias ${ }^{(b)}$ \\ ${ }^{(1 a, b)}$ Jurusan Teknik Elektromedik, Akademi Teknik Elektro Medik Semarang, \\ Semarang, Indonesia, 35141 \\ Email : ${ }^{\left(a^{*}\right)}$ mrofii@atemsemarang.ac.id, ${ }^{(b)}$ diahrahayu@atemsemarang.ac.id
}

Diterima (01 Desember 2021), Direvisi (05 Januari 2022)

\begin{abstract}
A person's condition can be known from the electrical activity of the heart that has been recorded and printed in the form of Elektrokardiogram (EKG). EKG data can be used in the study as a material modality for analysis and diagnosis of cardiac conditions. The data can be either one-dimensional or two-dimensional signal in the form of images. That can be processed by using a computer. This study is intended to prepare EKG image data in the next stage, both for analysis and diagnostic purposes through EKG image data. Can be expected to facilitate and display the optimal results for various studies with EKG image data modality. Algorithm that uses local thresholding methods of sauvola technique. Using a value of $R=128$ and $k=0.34$ has resulted in a clean segmented segment EKG image without grid. Looking at the MSE and PSNR results of each method shows a better result sauvola algorithm than the global thresholding.
\end{abstract}

Keywords: sauvola method, Electrocardiogram, MSE, PSNR

\begin{abstract}
Abstrak. Kondisi seseorang dapat diketahui dari aktivitas kelistrikan jantung yang telah direkam dan dicetak dalam bentuk Elektrokardiogram (EKG). Data EKG dapat digunakan dalam penelitian sebagai modalitas bahan untuk analisis dan diagnosis kondisi jantung. Data tersebut dapat berupa isyarat satu dimensi maupun isyarat dua dimensi dalam bentuk citra atau gambar. Pengolahan isyarat EKG yang diambil dari data cetak fisik dipindai untuk mendapatkan data digital sehingga dapat diolah dengan menggunakan komputer. Penelitian ini bertujuan untuk mempersiapkan data citra EKG dalam tahap pra pengolahan yang siap diolah pada tahap selanjutnya, baik untuk keperluan analisis maupun diagnosis melalui data citra EKG. Berdasarkan hasil pengolahan citra ini diharapkan dapat memudahkan dan menampilkan hasil yang optimal untuk berbagai penelitian dengan modalitas data citra EKG.Algoritma yang diterapkan menggunakan metode pengambangan lokal dari sauvola tecnique. Dengan menggunakan nilai R yang merupakan yaitu sebesar 128 dan nilai $\mathrm{k}=0,34$ yaitu nilai telah menghasilkan citra isyarat EKG tersegmentasi yang bersih tanpa grid. Dengan melihat nilai MSE dan PSNR dari masing-masing metode menunjukkan algoritma sauvola mendapatkan hasil yang lebih baik dari pengambagan global.
\end{abstract}

Kata kunci: metode sauvola, elektrokardiogram, MSE, PSNR

\section{PENDAHULUAN}

Penyakit kardiovaskuler adalah penyakit yang disebabkan gangguan fungsi jantung dan pembuluh darah. Berdasarkan data dari badan kesehatan dunia (WHO) menempatkan abnormalitas jantung sebagai urutan teratas daftar penyebab utama kematian di seluruh dunia [1]. Jantung merupakan suatu organ otot berongga yang terletak di pusat dada. Fungsi utama jantung adalah menyediakan oksigen ke seluruh tubuh dan membersihkan tubuh dari hasil metabolism (karbon dioksida). Jantung melaksanakan fungsi tersebut dengan mengumpulkan darah yang kekurangan 
oksigen dari seluruh tubuh dan memompanya kedalam paru-paru, dimana darah akan mengambil oksigen dan membuang karbon dioksida, jantung kemudian mengumpulkan darah yang kaya oksigen dari paru-paru dan memompanya ke jaringan di seluruh tubuh [2][3].

Fungsi vital yang diperankan oleh organ yang satu ini berpengaruh besar terhadap kondisi seseorang yang dapat dilihat dari isyarat yang dihasilkan oleh aktivitas kelistrikan jantung. Elektrokardiogram merupakan salah satu rekaman isyarat fisiologi utama yang dihasilkan dari aktivitas kelistrikan jantung baik ketika fase repolarisation maupun depolarization [4]. Elektrokardiogram (EKG) pertama kali diperkenalkan oleh Augustus Desire Waller pada tahun 1887.

Rekaman visual dari aktivitas kelistrikan jantung ini ditunjukkan sebagai garis bergelombang atau disebut "trace" seperti pada Gambar 1. Mesin yang menggunakan teknik seperti ini dikenal sebagai elektrokardiogram atau EKG. Sejak saat itu EKG menjadi salah satu isyarat yang penting dan paling sering digunakan untuk melakukan analisis terhadap aktivitas jantung [4][5][6] dan telah menjadi "gold standard" atau standar baku untuk diagnosis aritmia jantung [7].

Penelitian terhadap isyarat yang dihasilkan oleh jantung dengan menggunakan bantuan teknologi komputer sudah banyak dilakukan [8][9]. Berdasarkan hal tersebut dapat

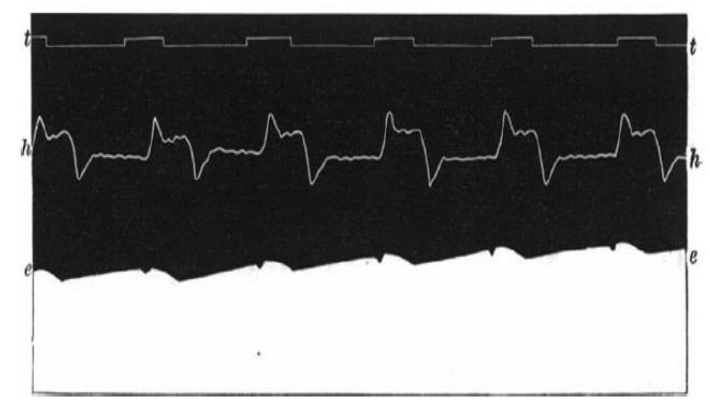

Gambar 1. Hasil EKG manusia pertama yang direkam pada 1887 oleh D.Waller (1856-1922) dimanfaatkan oleh dokter ataupun tenaga medis dalam membaca dan menganalisis isyarat jantung yang dapat menampilkan abnormalitas aktivitas jantung. Hal itu merupakan salah satu media bantu dibidang kedokteran yang diharapkan oleh semua orang dalam rangkan meningkatkan pelayanan kesehatan di seluruh dunia.

Dengan melihat bahwa kejadian abnormalitas jantung menempati urutan teratas benyebab kematian, sehingga hal tersebut menarik perhatian bagi orang untuk melakukan penelitian yang berkaitan kelistrikan jantung. Dari beberapa penelitian yang paling umum adalah melalui data rekaman EKG sebagai modalitas utama objek penelitian. Pada umumnya identifikasi terhadap abnormalitas jantung didasarkan pada isyarat EKG yang diolah dan dianalisis pada kawasan waktu (time domain), kawasan frekuensi (frequency domain), kawasan spasial (spatial domain), dan dengan analisis statistik non linear [10][11].

Pengolahan terhadap isyarat EKG pada umumnya melalui beberapa proses yang harus berjalan dengan baik, sehingga dapat diperoleh hasil yang akurat dan optimal. Dasar dari pada tahap pengolahan isyarat EKG pada umunya terdiri atas prapengolahan, ekstraksi ciri, dan identifikasi [12]. Masing-masing tahapan mempunyai pengaruh yang cukup penting dalam menentukan keberhasilan suatu sistem yang telah dibuat. Akan tetapi seluruh proses yang akan dijalankan tergantung pada proses awal dimana kita akan memulai sebuah tahapan ke tahap selanjutnya. Sehingga pada proses prapengolahan merupakan tahapan sangat penting dan menentukan kinerja suatu sistem untuk mendapatkan hasil yang optimal. Pada penelitian ini difokuskan pada pengolahan data citra EKG menggunakan metode sauvola pengambangan lokal sebagai salah satu 
solusi pada tahapan pra pengolahan citra EKG untuk analisis dan identifikasi kelistrikan jantung yang didasarkan pada data citra Elektrokardiogram.

Pengambangan merupakan suatu proses membuat citra biner dari citra grayscale dengan cara merubah kesuluruhan nilai piksel menjadi nol jika berada dibawah nilai ambang (threshold) dan nilai satu saat berada diatas nilai ambang. Terdapat dua pendekatan metode pengambangan yaitu pengambangan local (local threshold) dan pengambangan global (global threshold) [13]. Beberapa penelitian mengenai pengambangan berhubungan dengan pengolahan citra juga telah dilakukan oleh Ghaye dengan memaparkan tentang penjelajahan teknik-teknik adaptif pengambangan local dan pengambangn global untuk lab on chip system pengamatan nutrisi (nutrichip). Dalam penelitian tersebut digunakan ambang batas global (otsu, t-point) dan local (sauvola) yang dikombinasikan dengan morfologi matematika top hat (THMM) filter [14].

Metode tersebut digunakan untuk mengklasifikasikan citra yang besar dan hasilnya cukup baik. Rasmhi Saini melakukan studi komparasi terhadap beberapa metode pengambangan yang diterapkan pada pengalamatan masalahmasalah dan menangani informasi tekstual. Pengamatan terhadap penerapan binerisasi citra terkait dengan metode, konsep, kelebihan dan kekurangan dari beberapa metode tersebut didapatkan kesimpulan bahwa pengambangan lokal adaptif lebih baik dari pengambangan global. Secara khusus penggunakan pengambangan lokal dengan metode sauvola menunjukkan kelebihan terkait pemecahan masalah nois pada latar belakang (background) [15].

Berdasarkan latar belakang dari penelitian penelitian sebelumnya, maka metode sauvola sangat cocok digunakan dalam pengolahan citra EKG dengan tujuan untuk memisahkan citra latar belakang dengan citra yang telah disegmentasi.

\section{METODE PENELITIAN}

Bahan yang digunakan dalam
penelitian ini adalah data fisik
Elektrokardiogram (masih berbentuk data cetak di atas kertas grafik) yang diambil dari Rumah Sakit Umum Daerah Tugurejo Semarang yang selanjutnya dilakukan scanning untuk mendapatkan data digital berupa citra dua dimensi. Perancangan sistem pada penelitian ini terdiri atas beberapa tahapan.

Pada Gambar 2 menunjukkan beberapa tahapan untuk proses prapengolahan pada data rekaman EKG. Tahapan tersebut terdiri atas pengumpulan data analog (data fisik rekaman EKG) yang didapatkan dari rumah sakit. Selanjutnya data analog tersebut dilakukan proses scanning dengan tujuan untuk mendapatkan data digital berupa citra dua dimensi dengan format *.jpeg agar dapat diolah dengan menggunakan komputer. Setelah didapat data digital maka pada tahapan selanjutnya adalah penerapan pengambangan lokal dengan menggunakan algoritme sauvola sebagai metode pilihan untuk proses segmentasi sampai dihasilkan citra isyarat EKG yang bebas dari grid dan label.

\subsection{Thresholding (ambang batas) Dwi Aras}

Segmentasi yang paling sederhana dilaksanakan dengan menggunakan ambang intensitas. Nilai yang lebih kecil daripada nilai ambang diperlakukan sebagai area pertama dan yang lebih besar daripada atau sama dengan nilai ambang dikelompokkan sebagai area yang kedua. Dalam hal ini, salah satu area tersebut berkedudukan sebagai latarbelakang. Cara seperti itulah yang disebut ambang batas dwi aras (bilevel thresholding) atau terkadang dinamakan pengambangan intensitas [16]. Secara 
matematis, hal itu dinyatakan dalam praktik, nilai 1 atau 0 pada Persamaan 1 dapat dipertukarkan.

$$
b(y, x)=f(x)=\left\{\begin{array}{l}
1, \operatorname{untuk}(y, x) \geq T \\
0, \operatorname{untuk}(y, x)<T
\end{array}(1)\right.
$$

Dengan:

$b(y, x)=$ nilai piksel

$f(x)=$ fungsi koordinat $\mathrm{x}$ pada piksel

$\mathrm{T}=$ ambang intensitas

Peng-ambangan intensitas biasa digunakan untuk memisahkan tulisan hitam yang berada di atas secarik kertas putih. Namun, perlu diketahui, peng-ambangan ini mempunyai kelemahan, yaitu:

1) Tidak memperlihatkan hubungan spasial antarpiksel.

2) Sensitif terhadap pencahayaan yang tidak seragam. ideal

Hanya berlaku untuk keadaan yang

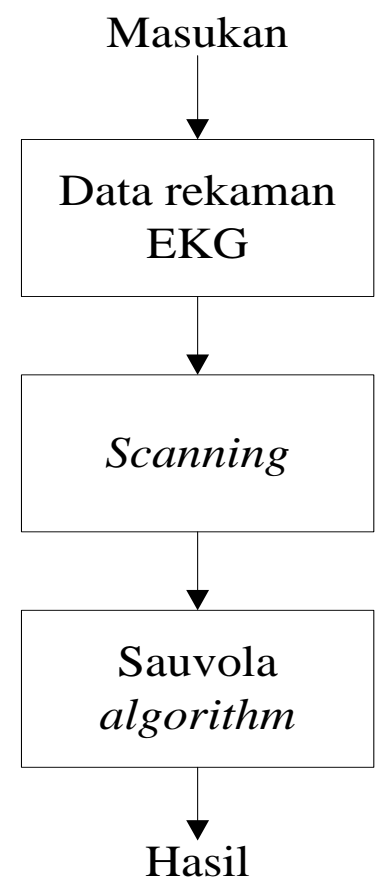

Gambar 2. Diagram blok perancangan system

3) (misalnya, latar belakang hitam dan objek berwarna putih).

\subsection{Pengambangan Global dan Local}

Terkait dengan nilai ambang yang digunakan pada segmentasi citra, terdapat istilah peng-ambangan global dan pengambangan lokal [17]. Pengertiannya sebagai berikut.

a) Apabila nilai ambang $t$ bergantung hanya pada satu nilai aras keabuan $\mathrm{f}(\mathrm{y}$, $\mathrm{x}$ ), peng-ambangan disebut sebagai global. Dalam hal ini, semua piksel dalam citra akan ditentukan oleh satu nilai ambang $\mathrm{t}$.

b) Pengambangan disebut lokal apabila nilai ambang $t$ bergantung pada $f(y, x)$ dan $\mathrm{g}(\mathrm{y}, \mathrm{x})$ dengan $\mathrm{g}(\mathrm{y}, \mathrm{x})$ menyatakan properti citra lokal pada titik (y, $\mathrm{x}$ ). Dalam hal ini, properti citra lokal dapat diperoleh melalui statistik (misalnya rerata tetangga di sekitar titik $(\mathrm{y}, \mathrm{x})$ ). Dengan kata lain, nilai ambang untuk setiap piksel ditentukan oleh nilai piksel tetangga. Dengan demikian, nilai ambang untuk piksel masing-masing belum tentu sama.

\subsection{Sauvola Algorithm}

Metode Sauvola merupakan jenis pengambagan lokal. Teknik ini dikembangkan oleh Sauvola and Pietikainen [18] dari teknik Niblack [19] dimana mereka sama-sama menggunakan nilai statistik dari citra. Local thresholding sendiri bekerja pada area-area kecil atau disebut dengan lokal/ blok dalam citra. Jadi proses penentuan nilai threshold dan thresholdingnya bekerja pada blok-blok dalam citra, sebagai contoh adalah blok berukuran 3x3. Biasanya blok ini disebut dengan window (jendela). Teknik ini sangat tergantung pada ukuran jendela/ blok nya. Ukuran jendela akan berpengaruh pada kualitas hasil binerisasi (thresholding). Citra yang bekerja untuk teknik ini adalah jenis grayscale (level keabuan). Rumus 
untuk menghitung nilai threshold $\mathrm{I}(\mathrm{i}, \mathrm{j}) \quad=$ nilai piksel citra asli pada menggunakan teknik ini adalah:

$T(x, y)=m(x, y)\left[1+k\left(\frac{\delta(x, y)}{R}-1\right)\right]$

\section{Dengan:}

$\mathrm{T}(\mathrm{x}, \mathrm{y})=$ nilai threshold untuk tiap blok $\mathrm{m}(\mathrm{x}, \mathrm{y})=$ nilai rata rata

$\delta(\mathrm{x}, \mathrm{y})=$ nilai standar deviasi

Nilai $\mathrm{k}$ dan $\mathrm{R}$ merupakan tetapan atau konstanta. Nilai R adalah 128 untuk citra abu-abu (grayscale) dan nilai berada pada rentang $\left[\begin{array}{ll}0.2 & 0.5\end{array}\right]$. Pada penelitiannya, Sauvola menggunakan nilai 0.5 begitu juga Sezgin [20].

Kedekatan antara teknik Sauvola dan Niblack terasa pada kondisi dimana terdapat kontras yang tinggi pada blok-blok tersebut, sebaliknya jika kontrasnya rendah maka threshold yang dihasilkan akan jauh berbeda. Dalam teknik ini, nilai k berfungsi untuk mengontrol nilai threshold lokal. Sehingga semakin besar nilai $\mathrm{k}$ maka semakin rendah nilai threshold dibandingkan rerata. Menurut Badekas [21], nilai $\mathrm{k}$ yang paling optimal adalah 0.34 . Tentu itu terbatas pada data penelitian yang mereka gunakan karena secara umum algoritma ini tidak sensitif terhadap perubahan nilai $\mathrm{k}$.

\subsection{Pengukuran kualitas Citra}

Mengukur kualitas citra digital pada prinsipnya adalah membandingkan citra yang diukur dengan citra aslinya. Kualitas citra dapat diukur dengan parameter sebagai berikut [22]:

1. Mean Square Error (MSE)

MSE memiliki formula yang ditunjukkan pada Persamaan 3 sebagai berikut :

$M S E=\frac{1}{m n} \sum_{i=0}^{m-1} \sum_{j=0}^{n-1}[I(i, j)-K(i, j)]^{2}$

Dengan:

MSE = nilai kesalahan kuadrat rata rata $\mathrm{m}$ dan $\mathrm{n}=$ dimensi citra yang akan diproses koordinat (i,j)

$\mathrm{K}(\mathrm{i}, \mathrm{j}) \quad=$ nilai piksel citra hasil perbaikan pada koordinat $(\mathrm{i}, \mathrm{j})$

\section{Peak Signal to Noise Ratio (PSNR)}

PSNR memiliki persamaan yang ditunjukkan pada Persamaan 4 berikut ini

$P S N R=10 \cdot \log _{10}\left(\frac{M A X_{i}^{2}}{M S E}\right)$

\section{Dengan:}

MAXi = nilai piksel maksimum pada citra asli

Nilai MSE yang diperoleh pada persamaan 3 disubtitusikan pada persamaan 4 sebagai pembagi nilai piksel maksimum pada citra asli. Nilai PSNR inilah yang menjadi pedoman apakah sebuah citra memiliki kualitas yang baik atau tidak.

\section{HASIL DAN PEMBAHASAN}

Penelitian ini dilakukan untuk mendapatkan data citra rekaman EKG tersegmentasi sebagai modalitas utama penelitian berdasarkan citra rekaman EKG, sehingga bebas dari grid latar belakang dan label yang ada pada rekaman tersebut. Data penelitian yang digunakan berasal dari Rumah Sakit Umum Daerah di kota
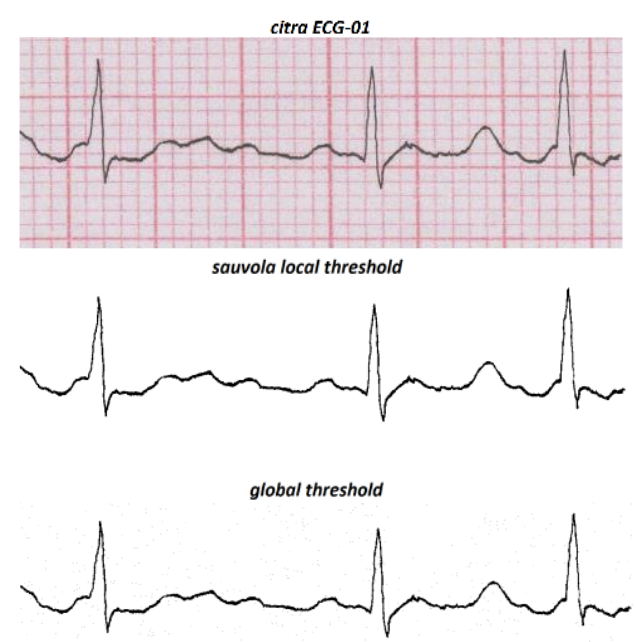

Gambar 3. Hasil segmentasi citra EKG-01 
Semarang. Penerapan algoritma Sauvola pada penelitian ini menggunakan nilai $\mathrm{R}$ sebesar 128 dan nilai $\mathrm{k}=0,34$ [21], bahwa dalam penelitiannya telah menguji beberapa rentang nilai antara 0,2 sampai 0,5 dan hasilnya nilai optimal berada pada nilai 0,34. Hasilnya dapat dilihat pada Gambar 3 sampai dengan Gambar 5 berikut ini:

Perbedaan nilai MSE dan PSNR dengan menggunakan dua metode berbeda yaitu Sauvola Local Thresholding dan Global Thresholding yang dihasilkan pada data EKG-01 dapat dilihat pada Tabel 1 berikut ini:

Tabel 1. Nilai MSE dan PSNR citra EKG-01

\begin{tabular}{cccc}
\hline \multicolumn{3}{c}{$\begin{array}{c}\text { Sauvola Local } \\
\text { Thresholding }\end{array}$} & Global Thresholding \\
\hline MSE (dB) & PSNR (dB) & MSE (dB) & PSNR (dB) \\
\hline 0.9764072 & 48.2684898 & 0.9774895 & 48.2636784
\end{tabular}
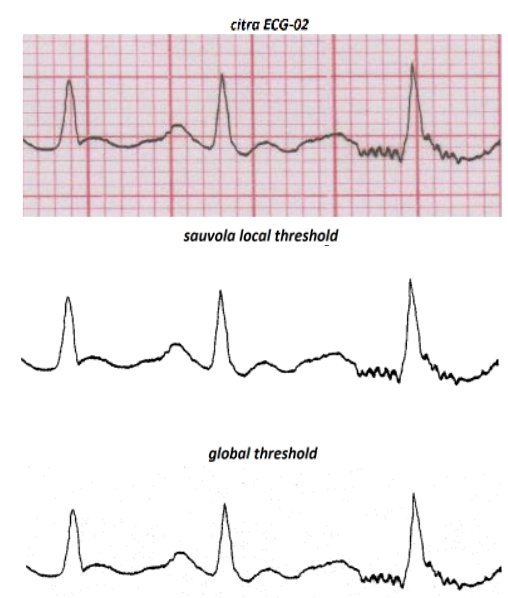

Gambar 4. Hasil segmentasi citra EKG-02

Tabel 2. Nilai MSE dan PSNR citra EKG-02

\begin{tabular}{llll}
\hline \multicolumn{3}{c}{$\begin{array}{c}\text { Sauvola Local } \\
\text { Thresholding }\end{array}$} & \multicolumn{2}{c}{ Global Thresholding } \\
\hline MSE (dB) & PSNR (dB) & MSE (dB) & PSNR (dB) \\
\hline 0.9768978 & 48.2663081 & 0.9780467 & 48.2612034 \\
\hline
\end{tabular}

Perbedaan nilai MSE dan PSNR dengan menggunakan dua metode berbeda yaitu Sauvola Local Thresholding dan Global Thresholding yang dihasilkan pada data EKG-02 dapat dilihat pada Tabel 2.
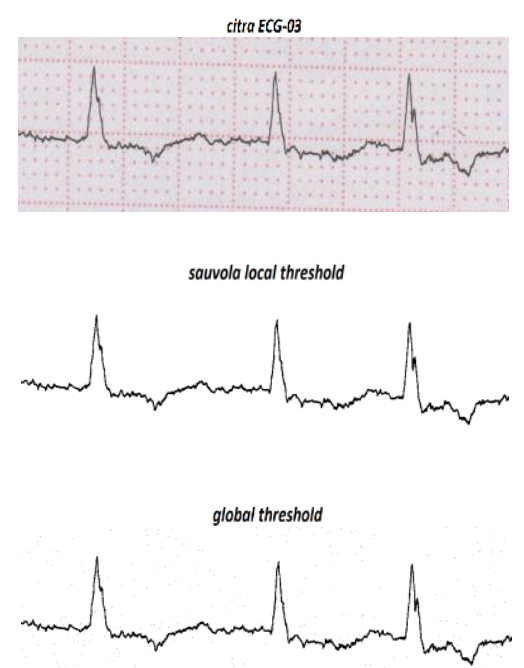

Gambar 5. Hasil segmentasi Citra EKG-03

Tabel 3. Nilai MSE dan PSNR citra EKG-03

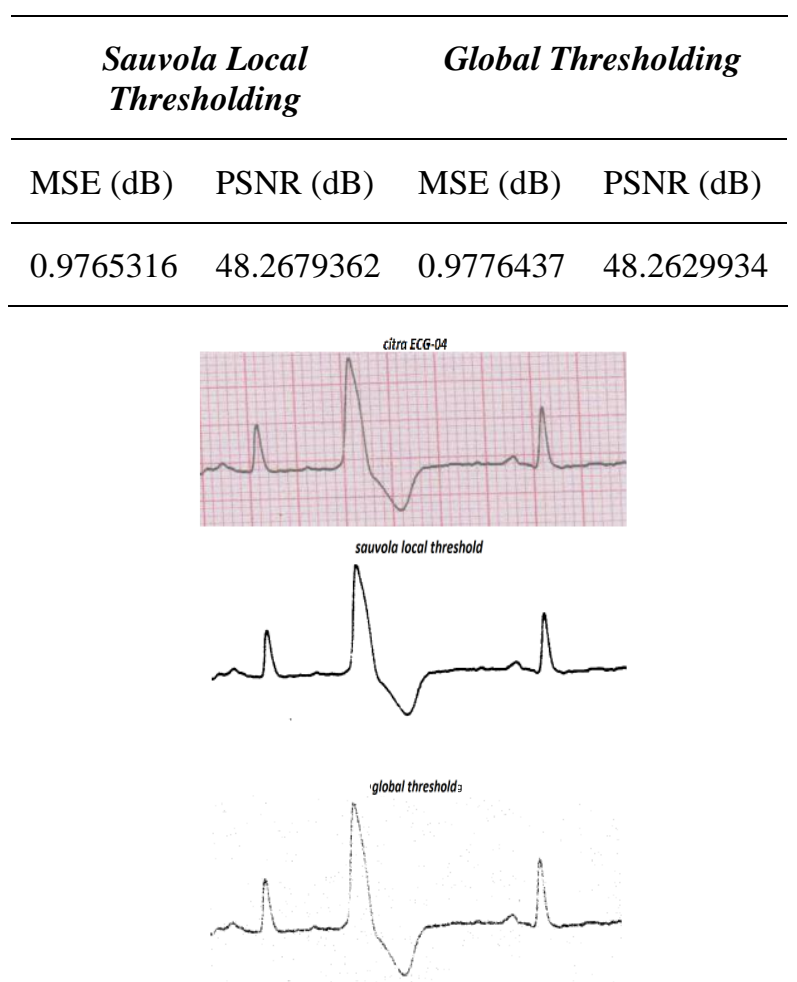

Gambar 6. Hasil segmentasi citra EKG-04

Perbedaan nilai MSE dan PSNR dengan menggunakan dua metode berbeda 
yaitu Sauvola Local Thresholding dan Global Thresholding yang dihasilkan pada data EKG-03 dapat dilihat pada Tabel 3 berikut ini:

Perbedaan nilai MSE dan PSNR dengan menggunakan dua metode berbeda yaitu Sauvola Local Thresholding dan Global Thresholding yang dihasilkan pada data EKG-04 dapat dilihat pada Tabel 4 berikut ini:

Tabel 4. Nilai MSE dan PSNR citra EKG04

\begin{tabular}{llll}
\hline \multicolumn{3}{c}{$\begin{array}{c}\text { Sauvola Local } \\
\text { Thresholding }\end{array}$} & \multicolumn{2}{c}{ Global Thresholding } \\
\hline MSE (dB) & PSNR (dB) & MSE (dB) & PSNR (dB) \\
\hline 0.9860242 & 48.2259236 & 0.9883115 & 48.2158606 \\
\hline
\end{tabular}

Tabel 5. Nilai MSE dan PSNR citra EKG05

\begin{tabular}{llll}
\hline \multicolumn{2}{c}{$\begin{array}{c}\text { Sauvola Local } \\
\text { Thresholding }\end{array}$} & \multicolumn{2}{c}{ Global Thresholding } \\
\hline MSE (dB) & PSNR (dB) & MSE (dB) & PSNR (dB) \\
\hline 0.9723261 & 48.2866799 & 0.9733254 & 48.2822188 \\
\hline
\end{tabular}

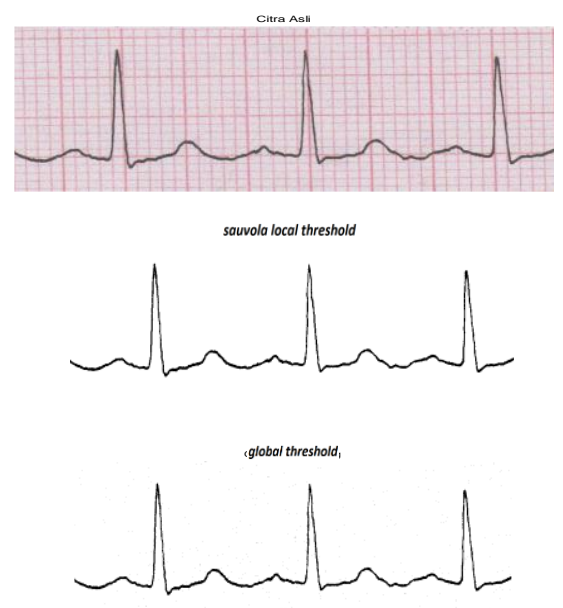

Gambar 7. Hasil segmentasi citra EKG-05

Perbedaan nilai MSE dan PSNR dengan menggunakan dua metode berbeda yaitu Sauvola Local Thresholding dan Global Thresholding yang dihasilkan pada data EKG-05 dapat dilihat pada Tabel 5.
Berdasarkan hasil yang ditunjukkan pada Gambar 3 sampai Gambar 7 dapat dievaluasi secara visual bahwa hasil segmentasi dengan menggunakan algoritme Sauvola menampilkan hasil yang lebih baik. Hal tersebut juga dikuatkan dengan penyajian Tabel 1 sampai Tabel 5 yang menampilkan hasil dari perhitungan nilai MSE dan PSNR dari masing-masing algoritme yang digunakan. Pada algoritme Sauvola semua nilai MSE didapatkan lebih kecil dari algoritme pengambangan global. sehingga dapat dikatakan kinerja dari metode Sauvola menunjukkan hasil yang lebih baik dibandingkan dengan pengambangan global. Begitu juga nilai dari PSNR yang telah didapatkan juga menunjukkan hasil yang lebih baik. Karena semakin besar nilai PSNR maka kualitas citra dapat dikatakan semakin baik. Sebaliknya jika nilai PSNR semakin kecil makan kualitas citra semakin buruk.

\section{KESIMPULAN}

Berdasarkan hasil penelitian dan pembahasan maka dapat disimpulkan bahwa algortma sauvola cukup baik dalam hal segmentasi citra EKG dibandingkan dengan metode pengambangan global. Berdasarkan nilai statistik MSE dan PSNR, disimpulkan bahwa proses peningkatan kualitas citra dengan menggunakan metode pengambangan lokal dari sauvola menghasilkan nilai yang lebih baik. Nilai MSE dan PSNR diukur berdasarkan nilai kesalahan kuadrat rata-rata. Nilai ini didapat dengan membandingkan nilai selisih piksel-piksel citra asal dengan citra hasil pada posisi piksel yang sama. Semakin besar nilai MSE, maka tampilan pada citra hasil akan semakin baik. Hal ini berbalikan dengan nilai PSNR, semakin besar nilai PSNR maka dapat dikatakan kualitas citranya semakin baik, tetapi semakin kecil nilainya, menandakan kualitas citranya juga semakin buruk. 


\section{DAFTAR PUSTAKA}

[1] WHO and World Health Organisation, "The 10 leading causes of death in the world, 2000 and 2012," 2014.

[2] L. Sherwood, "Human Physiology: From Cells to Systems," Hum. Physiol., vol. 7th editio, p. 766, 2010, doi: 9781111577438.

[3] J. E. Hall and A. C. Guyton, Guyton and Hall Textbook of Medical Physiology, vol. 53. 2011.

[4] A. D. Waller, "A Demonstration on Man of Electromotive Changes accompanying the Heart's Beat," $J$. Physiol., vol. 8, no. 5, pp. 229-234, Oct. 1887.

[5] R. Rangayyan, "Biomedical signal analysis," Library.Wisc.Edu. 2002.

[6] Chaudhuri, Subhasis, Pawar, T. D., Duttagupta, and Siddhartha, Ambulation Analysis in Wearable ECG. 2009.

[7] Braunwald E., Heart Disease: A Textbook of Cardiovascular Medicine, Fifth. Philadelphia, 1997.

[8] M. Velic, I. Padavic, and S. Car, "Computer aided ECG analysis State of the art and upcoming challenges," IEEE EuroCon 2013, no. July, pp. 1778-1784, 2013, doi: 10.1109/EUROCON.2013.6625218.

[9] M. Rofii, "Identifikasi Fibrilasi Atrium pada Isyarat Elektrokardiogram (EKG) Menggunakan Support Vector Machine (SVM)," Simetris J. Tek. Mesin, Elektro dan Ilmu Komput., vol. 9, no. 1, pp. 231-240, 2018.
[10] S. Hargittai, "Atrial fibrillation detection evaluation - performance measures," pp. 901-904, 2015.

[11] A. for the A. of M. Instrumentation, "ANSI/AAMI EC57: 2012-Testing and Reporting Performance Results of Cardiac Rhythm and ST Segment Measurement Algorithms," Am. Natl. Stand., 2013.

[12] R. M. Rangayyan, Biomedical image analysis. CRC press, 2004.

[13] S. N and V. S, "Image Segmentation By Using Thresholding Technique for Medical Images," Comput. Sci. Eng. An Int. J., vol. 6, no. 1, pp. 113, 2016, doi: 10.5121/cseij.2016.6101.

[14] J. Ghaye et al., "Image thresholding techniques for localization of subresolution fluorescent biomarkers," Cytom. Part A, vol. 83, no. 11, pp. 1001-1016, 2013, doi: 10.1002/cyto.a.22345.

[15] R. Saini, "Document Image Binarization Techniques , Developments and Related Issues : A Review," Int. J. Comput. Appl., vol. 116, no. 7, pp. 41-44, 2015.

[16] A. Susanto and A. Kadir, Teori dan Aplikasi Pengolahan Citra. yogyakarta: Andi, 2013.

[17] J. Rogowska, "Chapter 5 - Overview and Fundamentals of Medical Image Segmentation," I. N. B. T.-H. of M. I. P. and A. (Second E. BANKMAN, Ed. Burlington: Academic Press, 2009, pp. 73-90.

[18] J. Sauvola and M. Pietikäinen, "Adaptive document image binarization," Pattern Recognit., vol. 
33, no. 2, pp. 225-236, 2000, doi: 10.1016/S0031-3203(99)00055-2.

[19] K. Khurshid, I. Siddiqi, C. Faure, and N. Vincent, "Comparison of Niblack inspired binarization methods for ancient documents," Doc. Recognit. Retr. XVI, vol. 7247, no. February 2017, p. 72470U, 2009, doi: $10.1117 / 12.805827$.

[20] B. Sankur and M. Sezgin, "Image thresholding techniques: A survey over categories," Pattern Recognit., vol. 34, pp. 1573-1583, Jan. 2001.

[21] E. Badekas and N. Papamarkos, "A system for document binarization," pp. 909-914, 2004, doi: 10.1109/ispa.2003.1296408.

[22] M. Roopaei, M. K. Eghbal, M. Shadaram, and S. Agaian, "NoiseFree rule-Based fuzzy image enhancement," IS $T$ Int. Symp. Electron. Imaging Sci. Technol., pp. 1-5, 2016, doi: 10.2352/ISSN.24701173.2016.13.IQSP-225. 
Mohammad Rofi'i : Local Adaptive Thresholding Menggunakan Metode Sauvola sebagai Tahapan Pra Pengolahan pada Data Citra Isyarat EKG (Elektrokardiogram) 